\title{
Marrow hypoplasia: a rare complication of untreated Grave's disease
}

\author{
Hipoplasia de medula óssea: uma rara complicação \\ da doença de Graves não tratada
}

Juliana Garcia', Bruna Silveira Rodrigues', Larissa de França', Mônica Wolff', Renato Torrini', Vivian Ellinger', Carlos Campos', Vera Leal', Dayse Caldas'

\section{SUMMARY}

Atypical presentation forms of hyperthyroidism are always a challenge to the clinician. We present a female patient with the typical symptoms of thyrotoxicosis, without any thionamides treatment before, associated with pancytopenia, which recovered after euthyroidism state was achieved. Although the major cases of pancytopenia in Grave's disease are seen as a complication of antithyroid drugs (thioamides), in this case report the alteration in blood tests was associated with untreated hyperthyroidism. In the literature review, we found 19 case reports between 1981 to 2012, but it has been related to a hypercellular bone marrow with periferic destruction. Our case, however, is about a hypocellular bone marrow without fibrosis or fat tissue replacement, which proceeded with a periferic improvement following thyroid treatment. Although rare, pancytopenia, when present, may develop as an unusual and severe manifestation in untreated subjects. Arq Bras Endocrinol Metab. 2014;58(9):953-7

\section{SUMÁRIO}

Formas atípicas de apresentação do hipertireoidismo são sempre um desafio para o clínico. Apresentamos uma paciente do sexo feminino, com sintomas típicos de tireotoxicose associado a um quadro de pancitopenia sem nenhum tratamento prévio com tionamidas. A melhora da alteração hematológica ocorreu após recuperação do eutireoidismo. Embora a maioria dos casos de pancitopenia na doença de Graves seja uma complicação das drogas antitireoidianas (tionamidas), neste caso a alteração hematológica foi associada ao quadro de hipertireoidismo não tratado. Após uma revisão na literatura, encontramos 19 relatos de caso descritos no período de 1981 a 2012, nos quais o quadro de pancitopenia estava relacionado à hipercelularidade medular com destruição periférica das células sanguíneas. Nosso caso, entretanto, trata-se de uma pancitopenia com medula óssea hipocelular, sem infiltração por tecido adiposo ou fibrose, que evoluiu com melhora dos elementos do sangue periférico após tratamento do hipertireoidismo. Embora rara, a pancitopenia, quando presente, pode se manifestar como uma severa manifestação se não tratada a condição desencadeadora. Arq Bras Endocrinol Metab. 2014;58(9):953-7 ${ }^{1}$ Institute of Diabetes and
Endocrinology Luiz Capriglione
(IEDE), Rio de Janeiro, RJ, Brazil

Correspondence to:

Juliana Garcia

Rua Gildásio Amado, 55, sala 1901

22631-020 - Rio de Janeiro, RJ, Brazil

julianaagarcia@hotmail.com

Received on Jan/10/2014 Accepted on Apr/7/2014

DOI: 10.1590/0004-2730000003216

\section{INTRODUCTION}

G rave's disease (GD) usually presents with the several well-known symptoms and signs, but in some cases there is atypical manifestations of thyrotoxicosis, which include hematological alterations, as anemia. Pancytopenia is a rare, but a serious complication that physicians may come across.
Hyperthyroidism affects hematopoiesis in many ways, but its pathogenesis is still unclear. Both thyrotoxicosis and the underlying autoimmunity of GD may affect the production of blood cells. Imunological mechanisms are suggested to be involved, such as antineutrophil antibodies and antiplatelet antibodies, but the definitive ethiology remains uncertain. Neverthe- 
less, a good response to hyperthyroidism treatment is almost guaranteed.

\section{CASE REPORT}

A 54 year-old female was referred to our hospital complaining of palpitations, hand tremor and a $23 \mathrm{~kg}$ weight loss in the last 5 months. The physical examination revealed thyroid (approximately double the normal size), irregular, firm, without lumps, sinus tachycardia (120 bpm) with holosystolic murmur in the mitral focus, hypertension (BP $160 \times 100 \mathrm{mmHg}$ ) as well as moist and warm skin. There was no evidence of exophthalmos or pretibial myxedema. The patient was diagnosed with GD and stated never having been submitted to any previous treatment.
Besides the hyperthyroidism, her blood test results, at the time of the clinic visit included microcytic hypochromic anemia, thrombocytopenia, associated with neutrophilia (Table 1). We had her admitted for compensation of the thyroid disease and started treatment with Lithium - $900 \mathrm{mg} /$ day. After 18 days of treatment with Lithium, she was submitted to radioiodine I-131 (15 mci).

An evaluation by the hematology department (HEMORIO) was asked in order to rule out other possible causes of pancytopenia. They requested laboratory tests and proceeded with aspirate and biopsy of bone marrow. Due to the worsening of neutropenia (Table 1) treatment with granulocyte stimulating factor (G-CSF) was initiated.

Subsequent results of laboratory tests (HIV and viral hepatitis serology, B12 vitamin, serum iron, ferritin,

Table 1. Evolution of blood tests (hematological values, thyroid hormones and TSH receptor antibodies - TRAb)

\begin{tabular}{|c|c|c|c|c|c|c|c|c|c|c|c|}
\hline & $\begin{array}{c}\text { First } \\
\text { consult } \\
\text { without } \\
\text { any } \\
\text { anti- } \\
\text { thyroid } \\
\text { medica- } \\
\text { tion }\end{array}$ & $\begin{array}{l}\text { Started } \\
\text { Lithium }\end{array}$ & $\begin{array}{l}\text { With } \\
\text { Lithium } \\
900 \mathrm{mg} / \\
\text { day }\end{array}$ & $\begin{array}{c}\text { Before } \\
\text { Thera- } \\
\text { peutic } \\
\text { dose } \\
(09 / 26 / 12 \\
-\mid 131 \\
15 \mathrm{mci})\end{array}$ & $\begin{array}{l}\text { Started } \\
\text { G-CSF }\end{array}$ & & $\begin{array}{c}\text { After ten } \\
\text { days of } \\
\text { G-CSF }\end{array}$ & $\begin{array}{l}\text { Dischar- } \\
\text { ged }\end{array}$ & $\begin{array}{l}\text { Started } \\
\text { Propyl- } \\
\text { thiouracil }\end{array}$ & $\begin{array}{l}\text { Medica- } \\
\text { tions } \\
\text { suspen- } \\
\text { ded }\end{array}$ & $\begin{array}{c}\text { Started } \\
\text { Levo- } \\
\text { thyroxine }\end{array}$ \\
\hline Laboratory & $08 / 22 / 12$ & $09 / 06 / 12$ & $09 / 10 / 12$ & $09 / 24 / 12$ & $10 / 04 / 12$ & $10 / 07 / 12$ & $10 / 14 / 12$ & $10 / 17 / 12$ & $10 / 24 / 12$ & $01 / 24 / 13$ & $02 / 22 / 13$ \\
\hline $\begin{array}{l}\mathrm{Ht} / \mathrm{Hb} \\
\mathrm{RR}: 12 \text { to } \\
16 \mathrm{~g} / \mathrm{dL} / 36 \text { to } \\
48 \%\end{array}$ & $32,2 / 9,5$ & $30,6 / 9,5$ & $30,8 / 9,5$ & $27,6 / 8,5$ & $28,9 / 8,7$ & $26,3 / 7,8$ & $30 / 9,4$ & $32 / 10,3$ & $28,9 / 9,1$ & $42,3 / 12,8$ & $42,0 / 12,1$ \\
\hline $\begin{array}{l}\text { MCV/MCH } \\
\text { RR:80 to } \\
96 f \mathrm{f} / 27 \text { to } \\
33 \mathrm{pg}\end{array}$ & $72,2 / 21,3$ & $69,5 / 21,6$ & $68,8 / 21,2$ & $68 / 20,9$ & $68,6 / 20,7$ & $64,3 / 21$ & $69,4 / 21,8$ & $68,8 / 22,2$ & $70,7 / 22,2$ & $74,3 / 22,5$ & $80 / 25$ \\
\hline $\begin{array}{l}\text { WBC } \\
\text { RR: } 4000 \text { to } \\
11000 / \mathrm{mm}^{3}\end{array}$ & 2100 & 1900 & 1700 & $\underline{1200}$ & $\underline{1000}$ & $\underline{600}$ & 7100 & 2600 & 2200 & 3400 & 4600 \\
\hline $\begin{array}{l}\text { Neutrophils } \\
\text { RR:1640 T0 } \\
7920 / \mathrm{mm}^{3}\end{array}$ & 882 & 627 & 714 & $\underline{288}$ & $\underline{260}$ & $\underline{174}$ & 5396 & 1872 & 1122 & 2040 & 2896 \\
\hline $\begin{array}{l}\text { Platelets } \\
\text { RR: } 150000 \\
\text { to } 450000 / \\
\mathrm{mm}^{3}\end{array}$ & 137000 & 136000 & 122000 & 103000 & 140000 & 106000 & 141000 & 149000 & 170000 & 179000 & 187000 \\
\hline $\begin{array}{l}\text { TSH } \\
\text { RR:0,3 to 5,0 } \\
\mu \mathrm{Ul} / \mathrm{mL}\end{array}$ & $<0,011$ & - & $<0,011$ & - & - & - & - & - & $<0,011$ & 0,03 & 16,82 \\
\hline $\begin{array}{l}\text { Free T4 } \\
\text { RR: } 0,8 \text { to } \\
1,9 \mathrm{ng} / \mathrm{dL}\end{array}$ & 6,9 & 5,9 & 5,1 & - & 3,4 & 2,9 & 2,6 & 2,4 & 2,9 & 0,6 & 0,3 \\
\hline $\begin{array}{l}\text { TRAb } \\
\text { RR: }<1,5 \mathrm{UI} / \mathrm{L}\end{array}$ & $\underline{34}$ & - & - & - & - & - & - & - & $\underline{18,5}$ & - & - \\
\hline
\end{tabular}

Ht: hematocrit; Hb: hemoglobin; RR: reference range; MCV: mean corpuscular volume; MCH: mean corpuscular hemoglobin; WBC: white blood cell; TSH: thyroid stimulating hormone; TRAb: TSH receptor antibodies. 
DHL, ANA, VHS, hemoglobin electrophoresis) (Table 2 ) and the total abdominal ultrasonography were normal. The bone marrow biopsy revealed hypocellularity without any infiltration or fibrous/fatty tissue replacement (Figures 1 and 2).

After thirty-eight days of lithium, twenty days of radioiodine I-131 (15 mci) and ten days of G-CSF associated with decreased levels of thyroid hormones, improvement of pancytopenia could be noticed (Table 1). The patient was discharged after a 42 days period of

Table 2. Laboratory tests

\begin{tabular}{|c|c|}
\hline Laboratory & $9 / 12 / 12$ \\
\hline Anti-HIV & No reagent \\
\hline Anti-HBs & No reagent \\
\hline $\mathrm{HBs} \mathrm{Ag}$ & No reagent \\
\hline Anti-HBc & No reagent \\
\hline Anti-HCV & No reagent \\
\hline ANA & Negative \\
\hline ERS (RR: 0 to 15 mm/hour) & $2 \mathrm{~mm} / \mathrm{hora}$ \\
\hline LDH (RR: < 190 UI/I) & $101 \mathrm{UI} / \mathrm{I}$ \\
\hline B12 vitamin (RR: 180 to $914 \mathrm{pg} / \mathrm{mL}$ ) & $516 \mathrm{pg} / \mathrm{mL}$ \\
\hline Serum iron RR: 37 to $150 \mu \mathrm{g} / \mathrm{dL}$ ) & $46 \mu \mathrm{g} / \mathrm{dL}$ \\
\hline Ferritin (RR: 11 to $307 \mathrm{ng} / \mathrm{mL}$ ) & $198,2 \mathrm{ng} / \mathrm{mL}$ \\
\hline Transferrin saturation & 18\% (RV: 20 to 50\%) \\
\hline $\begin{array}{l}\text { Hemoglobin electrophoresis (Hg A1 RR: > 95\%; } \\
\text { Hg A2 RR: < 3,5\%; Fetal Hg RR: <0,5\%) }\end{array}$ & $\begin{array}{l}\mathrm{Hg} \mathrm{A1}: 96,4 \% ; \mathrm{Hg} \text { A2 } \\
3,4 \% ; \text { Hg Fetal 0,2\% }\end{array}$ \\
\hline Transferrin (RR: 200 to 360 mg/dL) & $233 \mathrm{mg} / \mathrm{dL}$ \\
\hline
\end{tabular}

Anti-HBs: hepatitis B surface antibody; HBs Ag: hepatitis B surface antigen; Anti-HBc: hepatitis B core antibody; Anti-HCV: hepatitis C antibody; ANA: antinuclear antibodies; ERS: erythrocyte sedimentation rate; LDH: lactate dehydrogenase; RR: reference range.

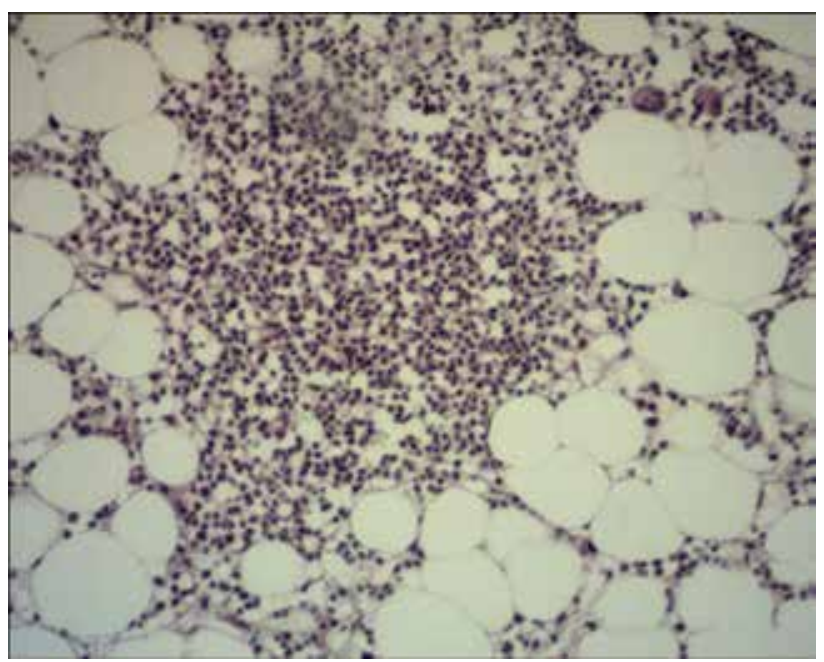

hospitalization with prescription for lithium $(900 \mathrm{mg} /$ day), and referral for our outpatient clinic.

She returned ten days after, as lab results were still abnormal (Table 1), propylthiouracil was added to the treatment with lithium. The decrease of thyroid hormones and complete improvement of pancytopenia finally occurred after two months of hospital discharge and the medications were therefore discontinued. Five months after the radioiodine treatment, she developed hypothyroidism. Levothyroxine was then initiated for the control of thyroid hormones.

\section{DISCUSSION}

Our patient presented with the classical signs and symptoms of hyperthyroidism due to diffuse toxic goiter (DTG), with the first lab results showing a pancytopenia that required investigation since she have never been submitted to any previous treatment. The American Thyroid Association as well as the American Association of Clinical Endocrinologists suggests that, prior to initiating antithyroid drug therapy (ATD), patients should have a complete blood count, and in case the patient has an absolute neutrophil count below $500 / \mathrm{mm}^{3}$ ATD is not recommended (item 15 of reference 1 ).

Since the main cause of hematological alteration in hyperthyroidism is known to be the treatment with thionamides, this would be a relative contraindication. Although, in a systematic review about agranulocytosis induced by nonchemotherapy drugs, it was shown that propiltiouracil rarely causes agranulocytosis, and low doses of MMI are even less likely to do so (2).

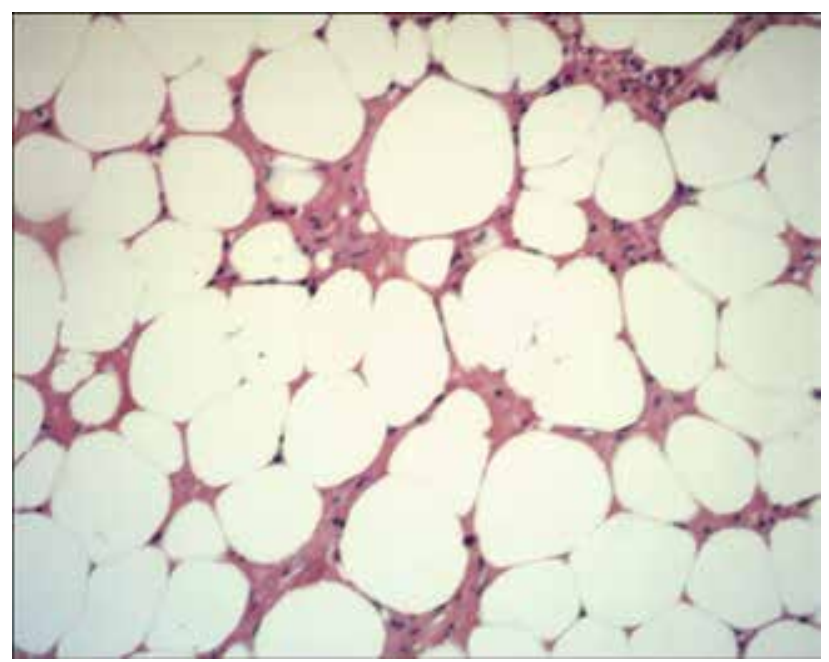

Figures 1 and 2. Marrow biopsy revealed hypocellularity without any infiltration or fibrous/fatty tissue replacement. 
Another study examined clinical features of hematopoietic disorders that occur after the administration of ATD. In a group of 50,385 patients analyzed in a Japanese hospital, only five developed pancytopenia after treatment for GD, and the majority patients who had been diagnosed with GD were treated with ATD. So, the incidence of pancytopenia in that study group can be estimated to have been minimal. In four of the patients in that study, pancytopenia was preceded by agranulocytosis. In addition, agranulocytosis and pancytopenia showed no manifest differences in their intervals of onset from the start of ATD administration. The authors suggest that these facts indicate, in this instance, these disorders could belong to the same disease with some probable overlap in their pathogenesis, only differing in severity. This would mean that ATD does damage hematopoietic stem cells. The pathogenic factors involved in erythropoietic organ disorders caused by ATD are diverse and require further research (3).

These evidences led us to choose the use of lithium as adjunct to RAI, so we could increase the radiation dose delivered to the thyroid (4). As seen in a retrospective cohort study that compared the efficacy of radioactive iodine therapy (RAI) given with or without concomitant lithium treatment in patients with newly diagnosed Graves' disease, patients treated with RAI plus lithium had a higher rate of recovery than those treated with RAI alone. In addition, patients treated with RAI and lithium were cured more rapidly than those treated with RAI alone. Treatment with lithium prevented serum free T4 increase after methimazole withdrawal and RAI therapy. At last, studies have shown that RAI is safe and except of transient or permanent iatrogenic hypothyroidism no significants outcomes have been reported (5). In a follow up study for 20 years, Ron and cols. didn't observe an increased mortality from cancer, including leukemia and hematological effects after low radioiodine therapy in GD. Cell killing, rather than mutation, should be the predominant effect $(6,7)$.

Regarding the pancytopenia, our approach was to rule out other causes such as HIV, viral hepatitis, deficiency of vitamin B12 or iron, collagenosis, hemoglobinopathy and hypersplenism. With the hematological service support (HEMORIO), we got the marrow's biopsy and aspirate, which indicated that there was a hypocellularity without any infiltration or fibrous/fatty tissue replacement. This suggested that the pancytopenia was due to a complication of hyperthyroidism itself, since improvement in the hematological alterations occurred with euthyroid state.

It is well known that GD is an autoimmune disease associated with hyperthyroidism. Both thyrotoxicosis and the underlying autoimmunity of GD affect multiple tissues and their functions, including hematopoesis. Anemia is common, resembles the anemia of chronic disease, and it corrects promptly with return to the euthyroid state following treatment (8).

The pathogenesis of DTG has been linked to genetic factors such as HLA-DR3 and cytotoxic T-lymphocyte antigen-4 (CTLA-4) and to environmental factors such as stress, female sex steroids, and certain infections (9).

As already mentioned, pancytopenia is a rare but serious complication of thyrotoxicosis. We found 19 case reports in a literature review between 1981 to 2012 , that made references to this relationship and all of them demonstrated reversible pancytopenia in response to hyperthyroidism's improvement. Single lineage abnormalities related to hyperthyroidism are more commonly reported than pancytopenia (5), e.g. anemia, and even in these cases it is demonstrated that after correction of hyperthyroidism an increase in hemoglobin values is detected, even in non-anemic patients $(8,10)$.

In a very interesting case where the patient had a protracted period of pancytopenia prior to hyperthyroidism, therapy with anti-thyroid led to a sustained improvement in his blood cell levels. The authors suggest that thyroid hormones may have a direct effect on hematopoiesis at a stage previous to erythropoietic stem cell differentiation, disturbing maturation and differentiation of the pluripotent stem cells (11). However, the exact pathogenic mechanism is still unclear, since hyperthyroidism could affect hematopoiesis in many ways (although clinically important abnormalities are rare). Some causes are suggested: ineffective hematopoiesis caused by an excess of thyroid hormones; reduction in blood cell life span caused by hypersplenism imunological mechanisms, such as antineutrophil antibodies and antiplatelet antibodies; toxicity of thyroid hormone to bone marrow stem cells $(12,13)$.

The major cases of pancytopenia in GD are seen as a complication of thioamides (14). When associated with untreated hyperthyroidism it has been related to a hypercellular bone marrow with periferic destruction (15). Our case, however, is about a hypocellular bone marrow without fibrosis or fat tissue replacement at the presentation of GD, which proceeded with a periferic improvement following thyroid treatment. 
Acknowledgment: thanks to MD Heloisa Miranda, chief hematology service at Hemorio, RJ, and to MD Vivian Pessoa, staff clinician at Hemorio, RJ.

Disclosure: no potential conflict of interest relevant to this article was reported.

\section{REFERENCES}

1. Bahn Chair RS, Burch HB, Cooper DS, Garber JR, Greenlee MC, Klein I, et al.; American Thyroid Association; American Association of Clinical Endocrinologists. Hyperthyroidism and other causes of thyrotoxicosis: management guidelines of the American Thyroid Association and American Association of Clinical Endocrinologists. Thyroid. 2011;21(6):593-646.

2. Andersohn F, Konzen C, Garbe E. Systematic review: agranulocytosis induced by nonchemotherapy drugs. Ann Intern Med. 2007;146(9):657-65.

3. Watanabe N, Narimatsu H, Noh JY, Yamaguchi T, Kobayashi K, Kami M, et al. Antithyroid drug-induced hematopoietic damage: a retrospective cohort study of agranulocytosis and pancytopenia involving 50,385 patients with Graves' disease. J Clin Endocrinol Metab. 2012;97(1):E49-53.

4. Dunkelmann S, Künstner H, Nabavi E, Eberlein U, Groth P, Schümichen $\mathrm{C}$, et al. Lithium as an adjunct to radioiodine therapy in Graves' disease for prolonging the intrathyroidal effective half-life of radioiodine. Useful or not? Nuklearmedizin. 2006;45(5):213-8.

5. Aizawa Y, Yoshida K, Kaise N, Fukazawa H, Kiso Y, Sayama N, et al. The development of transient hypothyroidism after iodine-131 treatment in hyperthyroid patients with Graves' disease: prevalence, mechanism and prognosis. Clin Endocrinol (Oxf). 1997;46(1):1-5.
6. Cooper DS. Radioiodine for hyperthyroidism: where do we stand after 50 years? JAMA. 1998;280(4):375-6.

7. Bogazzi F, Giovannetti C, Fessehatsion R, Tanda ML, Campomori A, Compri E, et al. Impact of lithium on efficacy of radioactive iodine therapy for Graves' disease: a cohort study on cure rate, time to cure, and frequency of increased serum thyroxine after antithyroid drug withdrawal. J Clin Endocrinol Metab. 2010;95(1):201-8.

8. Gianoukakis AG, Leigh MJ, Richards P, Christenson PD, Hakimian $A$, Fu $P$, et al. Characterization of the anaemia associated with Graves' disease. Clin Endocrinol (Oxf). 2009;70(5):781-7.

9. Chaar BT, Kudva GC, Olsen TJ, Silverberg AB, Grossman BJ. Thrombotic thrombocytopenic purpura and Graves disease. Am J Med Sci. 2007;334(2):133-5.

10. Nightingale S, Vitek PJ, Himsworth RL. The haematology of hyperthyroidism. Q J Med. 1978;47(185):35-47.

11. Shaw $B$, Mehta AB. Pancytopenia responding to treatment of hyperthyroidism: a clinical case and review of the literature. Clin Lab Haematol. 2002;24(6):385-7.

12. Akoum R, Michel S, Wafic T, Emile B, Marwan M, Khaled H, et al. Myelodysplastic syndrome and pancytopenia responding to treatment of hyperthyroidism: peripheral blood and bone marrow analysis before and after antihormonal treatment. J Cancer Res Ther. 2007;3(1):43-6.

13. Chen YH, Lin HJ, Chen KT. Rare presentations of hyperthyroidism-Basedow's paraplegia and pancytopenia. Am J Emerg Med. 2009;27(2):258.e1-2.

14. Lima CS, Zantut Wittmann DE, Castro V, Tambascia MA, LorandMetze I, Saad ST, et al. Pancytpenia in untreated patients with Grave's disease. Thyroid. 2006;16(4):403-9.

15. Low B-H, Victor Kok VC-K. Hyperthyroidism with pancytopenia: a case report and literature review. Formos J Endocrin Metab. 2009;1(1):23-8. 